\title{
EMOTIONAL INTELLIGENCE AND JOB SATISFACTION AMONG MEDICAL TEACHING FACULTY
}

\author{
Uzma Bano, Anis Ahmed*, Shahid Aziz, Noreen Tassadaq**, Omar Ahsan, Minahil Wasim*** \\ Foundation University Medical College Islamabad Pakistan, *Rawalpindi Medical College \& Allied Teaching Hospitals, Rawalpindi Pakistan, **Fauji Foundation \\ Hospital, Rawalpindi, Pakistan, ${ }^{* * *}$ Shifa College of Medicine Islamabad Pakistan
}

\begin{abstract}
Objective: To measure the correlation between emotional intelligence (EI) and job satisfaction (JS) among teaching faculty of Foundation University Medical College.

Study Design: Cross-sectional study.

Place and Duration of Study: Study was carried out at Foundation University Medical College (FUMC), Islamabad, from Mar to Apr 2021.

Methodology: Participants were recruited through survey sampling using "Google Forms."Faculty members with a total teaching experience of more than 05 years in FUMC were included in the study. EI was measured using Wong and Law Emotional Intelligence scale- Short version (WLEIS), while JS was measured using Brayfield and Rothes scale on a 5-point Likert scale. Data was entered and analyzed using SPSS version 17. The WLEIS score was correlated to the JS score using Pearson r correlation.

Results: Total 89 faculty members had a teaching experience of more than 5 years. Survey had a response rate of $76.4 \%$. Study included 68 faculty members; 26 (38.2\%) were from basic sciences and 42 (61.8\%) were from clinical sciences. The mean EI score was $3.22 \pm 0.70$; and the mean JS satisfaction score was $3.05 \pm 0.86$. All facets of emotional intelligence as well as overall emotional intelligence scores showed significant positive correlation with job satisfaction scores; which were statistically significant; $p<0.05$.

Conclusion: There was a statistically significant positive correlation between all components of emotional intelligence and job satisfaction. Hence, it is important for the medical colleges to concentrate on those practices that promote emotional intelligence among their teaching faculty.
\end{abstract}

Keywords: Career success, Emotional intelligence, Job satisfaction.

This is an Open Access article distributed under the terms of the Creative Commons Attribution License (http://creativecommons.org/licenses/by/4.0), which permits unrestricted use, distribution, and reproduction in any medium, provided the original work is properly cited.

\section{INTRODUCTION}

Teaching faculty members have an important role to play in medical students' intellectual, social and emotional development. Aristotle very rightly said, "those who educate children well are more to be honored than parents, for these only gave life, those the art of living well".

Job satisfaction is defined as "people's affective relation to their work role and their perceived relationship between what they want from job and what they perceived it was offering"1. Job satisfaction is important among teaching faculty since it is a determinant of their commitment, retention and effectiveness.

Emotional intelligence is one's ability to perceive and control one's own emotions as well those of others, to use emotional information to guide their thinking and behavior and to adjust emotions to adapt to different environments ${ }^{2}$. Recently, some researchers have suggested that emotional intelligence can be learned and strengthened ${ }^{3}$, whereas others believe that it is an

Correspondence: Dr Uzma Bano, Professor of Medicine, Foundation University Medical College Rawalpindi Pakistan

Received: 22 Apr 2021; revised received: 25 Apr 2021; accepted: 26 Apr 2021 inborn characteristic.

Researchers have found that emotional intelligence can be more important than IQ in overall success in career and life conversely low emotional intelligence can result in negative consequences for academic and professional achievement. Those individuals who are highly emotional intelligent are inclined to show better performance in their institutes in comparison to individuals who are low on emotional intelligence ${ }^{4}$. Indeed, the progress and success of any institute depends on its human resources.

There are four different components of emotional intelligence 5 . The first one is "perception of emotions" which means one's ability to be aware of one's own emotions and to convey ones emotions correctly to others. The second one is "integration of emotions" that is ones potential to distinguish among distinct emotions, and to acknowledge those who are affecting his ideas. The third one is "understanding of emotions" that is the capacity to recognize complex emotions. The fourth one is "management of emotions" which means to adopt or quit an emotion depending on its effectiveness under a given situation ${ }^{6}$. 
For any organization to achieve its goals it should be able to effectively manage its human resources. Outstanding performance of an educational institution needs a conducive environment and promotion of good interpersonal relationships. It has been found that job satisfaction has a direct association with an individual's success and with overall efficiency and productivity of an organization ${ }^{7}$.

There is limited research that emotional intelligence is related to positive career outcomes like promotions and job satisfaction in the medical education sector. The purpose of this study is to identify the relationship between medical teachers' emotional intelligence and their job satisfaction (figure). If a positive relation is identified EI assessment rather than IQ assessment at the time of induction into faculty should be the main aim. Furthermore the medical institutes should devise strategies to improve EI of their faculty.

\section{METHODOLOGY}

It was a cross-sectional study carried out at Foundation University Medical College (FUMC), Islamabad from March to April 2021. Approval was taken from the college ethics review committee. Total faculty members in FUMC are approximately 200. Participants were recruited through survey sampling using "Google Forms," and WhatsApp link of the questionnaire. Informed consent was taken from the faculty member at the beginning of online survey form. Confidentiality was maintained by the anonymity of data, since the faculty member did not hand over the data in person, instead they were provided with a WhatsApp link through which they responded to the survey. The survey questionnaire did not require them to mention their names, ages or departments.

All faculty members with a total teaching experience of more than 5 years in FUMC were included in the study. Faculty members absent on the days on sampling were excluded from study.

Emotional intelligence was measured using Wong and Law Emotional Intelligence scale- Short version

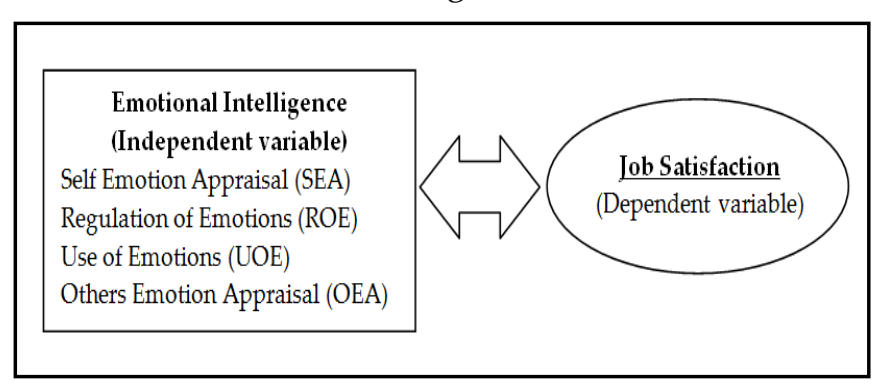

Figure: Conceptual framework of the study.
(WLEIS) $^{8}$. It consisted of 16 brief statements across four dimensions; self-emotion appraisal, appraisal of others emotions, use of emotions and regulation of emotions. Each item was scored on a 5-point Likert scale (table-I). The WLEIS calculates a global emotional intelligence score, with a higher score indicating greater emotional intelligence.

Job satisfaction was measured using the scale designed by Brayfield and Rothes ${ }^{9}$. Each item was again scored on a 5-point Likert scale (table-I). Item numbers 3 and 5 were reverse scoring items. The items included in this scale are; "I feel fairly well satisfied with my present job", "Most days I am enthusiastic about my work", "Each day of work seems like it will never end" (reverse scoring item), "I find real enjoyment in my work", and "I consider my job rather unpleasant" (reverse scoring item).

The survey questionnaire had three parts; Part 1: It was designed to collect demographic details like gender and total teaching experience; Part 2: It measured job satisfaction using five items taken from the Brayfield and Rothes job satisfaction scale; Part 3: it measured Emotional intelligence using the Wong and Law Emotional Intelligence Scale (WLEIS) Inventory.

Data was entered and analyzed using SPSS version 17. Job satisfaction was scored on a likert scale and total numerical score was presented as mean \pm SD. For two items (\# 3 \& 5) the scores were reversed. The total EI score was calculated from the WLEIS scale. The WLEIS score was correlated to the job satisfaction score using Pearson $r$ correlation. Correlation coefficients between 0.10 and 0.29 represent a small association, coefficients between 0.30 and 0.49 represent a medium association, and coefficients of 0.50 and above represent a large association or relationship.

\section{RESULTS}

The current faculty strength is approximately 200 faculty members; 91 basic sciences and 109 clinical sciences. Total 89 faculty members had a job experience of more than 05 years i.e. (target population). The study received response from 68 faculty members; hence a response rate of $76.4 \%$. Out of the study participants $26(38.2 \%)$ were from basic sciences and 42 $(61.8 \%)$ were from clinical sciences. Female faculty members were 44 (64.7\%).

Table-II shows the overall emotional intelligence with mean score and SD with mean scores of different components of emotional intelligence. Since there were sixteen questions to assess emotional intelligence and 
each question could be scored from 1-5; hence the emotional intelligence of each faculty member can range from 16-80 (minimum to maximum). The overall total emotional intelligence score per faculty member was $48.32 \pm 0.86$. The average emotional intelligence score per item was $3.22 \pm 0.70$.

Table-I: Five point likert scale.

\begin{tabular}{l|c}
\hline Scale Option & Score \\
\hline Strongly disagree & 1 \\
\hline Disagree & 2 \\
\hline Neutral / Undecided & 3 \\
\hline Agree & 4 \\
\hline Strongly agree & 5 \\
\hline
\end{tabular}

Table-II: Emotional intelligence and its component scores among the faculty members.

\begin{tabular}{l|c}
\hline Component of emotional intelligence & Mean \pm SD \\
\hline $\begin{array}{l}\text { Total emotional intelligence score (per } \\
\text { faculty members) }\end{array}$ & $48.32 \pm 0.86$ \\
\hline Average emotional intelligence score & $3.22 \pm 0.70$ \\
\hline Self Emotion Appraisal & $3.24 \pm 0.83$ \\
\hline Regulation of Emotions & $3.02 \pm 0.70$ \\
\hline Use of Emotions & $3.27 \pm 0.91$ \\
\hline Others Emotion Appraisal & $3.35 \pm 0.78$ \\
\hline
\end{tabular}

Table-III: Correlation between emotional intelligence and job satisfaction.

\begin{tabular}{l|c|c}
\hline $\begin{array}{l}\text { Component of emotional } \\
\text { intelligence }\end{array}$ & $\begin{array}{c}\text { Pearson } \\
\text { correlation (r) }\end{array}$ & Sig. (p) \\
\hline $\begin{array}{l}\text { Average emotional intelligence } \\
\text { score }\end{array}$ & 0.796 & .000 \\
\hline Self Emotion Appraisal & 0.741 & .000 \\
\hline Regulation of Emotions & 0.709 & .000 \\
\hline Use of Emotions & 0.750 & .000 \\
\hline Others Emotion Appraisal & 0.579 & .000 \\
\hline
\end{tabular}

The first four items of WLEIS that constituted Self Emotion Appraisal (SEA) were; "I have a good sense of why I feel certain feelings most of the time", "I have a good understanding of my own emotions", "I really understand what I feel", and "I always know whether I am happy or not". The average score for SEA was 3.24 \pm 0.83 .

Item number 5-8 of WLEIS constituted the Regulation of Emotions (ROE) component of EI. They consisted of "I always know my friends emotions from their behavior", "I am a good observer of others emotions", "I am sensitive to the feelings and emotions of others" and "I have a good understanding of the emotions of people around me". The average score for ROE was $3.02 \pm 0.70$.

Item number 9-12 of WLEIS constituted the Use of Emotions (UOE) component of EI. They consisted of "I always set goals for myself and then try my best to achieve them", "I always tell myself I am a competent person", "I am a self-motivating person", and "I would always encourage myself to try my best". The average

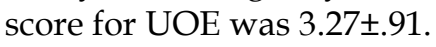

Item number 13-16 of WLEIS constituted the Others Emotion Appraisal (OEA) component of EI. They consisted of "I am able to control my temper so that I can handle difficulties rationally", "I am quite capable of controlling my own emotions", "I can always calm down very quickly when I am very angry", and "I have good control of my emotions". The average score for OEA for the study group was $3.35 \pm$ 0.78 .

The mean job satisfaction score was $3.05 \pm 0.86$. Table-III presents the correlation between job satisfaction scores and emotional intelligence scores. All facets of emotional intelligence as well as overall emotional intelligence scores showed a large or strong positive correlation with job satisfaction scores; all of which were statistically significant; $p<0.05$.

\section{DISCUSSION}

The objective of the current study was to explore the relationship between job satisfaction of medical teaching faculty and their emotional intelligence. Results indicated that there is a strong correlation between the two variables. The higher the emotional intelligence the higher was the job satisfaction. These results are in accordance with the predictions of Goleman $^{10}$.

A local study showed a significant correlation between emotional intelligence and academic performance of medical students ${ }^{11}$. Another local study showed emotional intelligence to be positively correlated with job satisfaction among librarians ${ }^{12}$. Another local study found that the five dimensions of emotional intelligence including managing relations, emotional stability, self-development, integrity and altruistic behavior were significant predictors of job satisfaction among secondary school heads in Khyber Pakhtunkhwa ${ }^{13}$. Studies from other countries have shown similar results $4,15,16$. However, some studies have reported a neg-ative correlation between these two variables ${ }^{17}$.

Emotions are a very important component of our life. People who handle their own emotions and others emotions around them appropriately are said to be emotionally intelligent. These people have better performance in academics and in professional spheres. Some experts believe that this quality is more important than IQ in determining their academic and career 
success. Goleman in 1995 predicted that IQ makes only $20 \%$ contribution to a person's success and the rest results from emotional intelligence. He predicted that emotionally intelligent people have success in education, work-place, social interactions and marital relationships ${ }^{10}$. One of the most important challenges for working people is to achieve a work-life balance and general life satisfaction. Feelings of accomplishment and satisfaction with ones job are a measure of their career success ${ }^{18}$. Lack of job satisfaction leads to higher absenteeism from workplace, reduced creativity and productivity, hostility and increased job turnover.

People with higher emotional intelligence are capable of regulating and controlling emotions in themselves and in other individuals ${ }^{19}$. Such individuals avoid negative emotions and immediately return to favorable condition. Emotional intelligence assessments should be a part of selection criteria while inducting new teaching faculty and all reliance should not be placed on merit criteria alone. Fostering EI among students and teachers both should be the top priority in medical colleges. To boost up the emotional intelligence level, firstly identify the emotionally intelligent faculty with good communication skills, self-management skill and healthy relationships. Secondly, build a strong knowledge base about EI by engaging experts to teach EI concepts and strategies. Thirdly, formulate a vision for success through curricular and co-curricular approaches; for example by organizing workshops, seminars, and conferences, or by offering curriculum innovation grants.

This study does have certain limitations. Firstly, only a quantitative study design has been used. A mixed method study design i.e. could have yielded more robust evidence. Secondly, standardized tools were used for the study, whereas a self-developed validated instrument may have been more powerful. Thirdly, demographic variables like age, job experience, academic and professional qualifications, job designation and locality can influence the study findings. These confounding variables were not taken into account during data analysis. Fourthly, the study was carried out in a private medical college. Future studies can be carried out to include public sector medical colleges. Finally, collection of data from multiple medical colleges with a larger sample size can improve the robustness of results.

\section{CONCLUSION}

There was a strong positive and statistically significant correlation between emotional intelligence and job satisfaction. Moreover, this positive and statistically significant correlation was seen between job satisfaction and all components of emotional intelligence namely; self emotion appraisal, regulation of emotions, use of emotions, and others emotion appraisal. Therefore, it is important to concentrate on those practices that promote emotional intelligence among medical teaching faculty. These can be indispensible for the progress of the medical college.

\section{CONFLICT OF INTEREST}

This study has no conflict of interest to be declared by any author.

\section{REFERENCES}

1. UK Essays. The concept and definition of job satisfaction. 2018 Available from: https://www.ukessays.com/essays/psychology /the-concept-and-definition-of-job-satisfaction-psychologyessay.php?vref $=1$.

2. Goleman D, New York, NY: Bantam Books; 1998. Working with emotional intelligence.

3. Gilar-Corbi R, Pozo-Rico T, Sánchez B, Castejón JL. Can emotional intelligence be improved? A randomized experimental study of a business-oriented EI training program for senior managers. PLoS One 2019; 14(10): e0224254.

4. Van-Rooy DL, Alonso A, Viswesvaran C. Group differences in emotional intelligence scores: Theoretical and practical implications. Pers Individ Dif 2005; 38(3): 689-700.

5. Mayer JD, Salovey P. "What is emotional intelligence?," in Emotional development and emotional intelligence: Implications for educators, eds Salovey P, Sluyter D. New York, NY: Basic Books 1997: 3-31.

6. Salovey P, Mayer J. Emotional Intelligence. Imagination, Cognition, and Personality 1990; 9(3): 185-211.

7. Wang W, Li J, Sun G, Cheng Z, Zhang X. Achievement goals and life satisfaction: the mediating role of perception of successful agency and the moderating role of emotion reappraisal. Psicologia: Reflexão e Crítica 2017; 30: 25.

8. Libbrecht N, Lievens F, Schollaert E. Measurement equivalence of the wong and law emotional intelligence scale across self and other ratings. Educ Psychol Meas 2010; 70(6): 1007-20.

9. Brayfield $\mathrm{AH}$, Rothe HF. An index of job satisfaction. J Appl Psychol 1951; 35: 307-11.

10. Goleman D. Emotional intelligence. New York USA: Bantam Books; 1995.

11. Zaman S, Mahboob U. Correlation of emotional intelligence with academic achievement in undergraduate medical students. Adv Health Prof Educ 2016; 2(1): 20-23.

12. Khan A, Masrek MN, Nadzar FM. Emotional intelligence and job satisfaction of academic librarians: an assessment of the relationship. J Librariansh Inform Sci 2017; 49: 199-210.

13. Suleman Q, Syed MA, Mahmood Z, Hussain I. Correlating emotional intelligence with job satisfaction: evidence from a cross-sectional study among secondary school heads in Khyber Pakhtunkhwa, Pakistan. Front Psychol 2020; 11: 240.

14. Ghoreishi FS, Zahirrodine AR, Assarian F, Gholam SA. Evaluation of emotional intelligence and job satisfaction in employees of Kashan Hospitals. Nurs Midwifery Stud 2014; 11977.

15. Hü lya Gü ndü z Çekmecelioğlu. Effects of emotional intelligence on job satisfaction: An empirical study on call center employees. Procedia Soc Behav Sci 2012; 58: 363-69. 
16. Urquijo I, Extremera N, Azanza G. The contribution of emotional intelligence to career success: beyond personality traits. Int J Environ Res Public Health 2019; 16(23): 4809.

17. UK Essays. Emotional intelligence and job satisfaction psychology essay. 2018 Available from: https://www.ukessays.com/ essays/psychology/emotional-intelligence-and-job-satisfactionpsychology-essay.php?vref $=1$
18. Spurk D, Hirschi A, Dries N. Antecedents and outcomes of objective versus subjective career success: competing perspectives and future directions. J Manag 2019; 45: 35-69.

19. Wijekoon $\mathrm{CN}$, Amaratunge $\mathrm{H}$, de Silva $\mathrm{Y}$, Senanayake S, Jayawardane P. Emotional intelligence and academic performance of medical undergraduates: a cross-sectional study in a selected university in Sri Lanka. BMC Med Educ 2017; 17: 176. 